\title{
Transient Transformation of Maize BMS Suspension Cells via Particle Bombardment
}

Liang-Zi Zhou* and Thomas Dresselhaus*

Cell Biology and Plant Biochemistry, University of Regensburg, Universitätsstraße 31, 93053 Regensburg, Germany

*For correspondence: liangzi.zhou@ur.de; thomas.dresselhaus@ur.de

[Abstract] Maize is one of the most important crop species and serves also as a model plant for grass research. A major bottleneck in maize research is stable transformation, which is both time and cost consuming, but also a technical challenge for most labs due to limited access to sufficient and optimal plant growth facilities. However, many studies in maize cell biology, physiology and biochemistry don't require stable transformed plants and can be accomplished by using transiently transformed suspension cultures. Here, we report a detailed protocol to establish Black Mexican Sweet (BMS) maize suspension cell cultures and transiently transform it via particle bombardment. We demonstrate how reliable subcellular protein localization data can be obtained within a very short time period and analyzed using open access software.

Keywords: Particle bombardment, Transient transformation, BMS suspension cells, Co-localization analysis, Maize

[Background] Maize is indispensable for producing food, animal feed, industrial products and biofuels. Thus, continuous research to improve its germplasm will be fundamental to meet increasing global demands under challenging environmental conditions (Shiferaw et al., 2011). Moreover, maize has also served as a genetic system and model species for grass research for over a century (e.g., Dresselhaus et al., 2011). The availability of the first genome sequence of the maize inbred line B73 in 2009 (Schnable et al., 2009) and reference genomes of additional inbred lines in successive years (e.g., Jiao et al., 2017; Sun et al., 2018) further fueled its usage as a model and crop plant. Unfortunately, functional studies of maize genes are still difficult and only a few academic labs have established efficient maize transformation systems. Limitations include access to state-of-the-art growth facilities required to achieve high and efficient transformation rates. Although highly efficient transformation methods have been reported recently (e.g., Anand et al., 2019), its routine use is restricted to labs experienced in maize transformation that possess also access to excellent plant growth facilities.

However, stable maize transformation is not always necessary as a number of analyses including primary studies using large sets of candidate genes can also be done using cell cultures. Subcellular localization analysis of candidate proteins, for example, is essential to understand gene functions. The majority of studies investigating the subcellular localization of maize proteins used heterologous systems including onion epidermal cells as well as leaves and suspension cells of tobacco (e.g., Amien et al., 2010; Juranić et al., 2012). These systems might lack important components for proper protein localization and often form large aggregates likely due to mis-folding of heterologous proteins (e.g., 
Srilunchang et al., 2010). Here, we describe a transient transformation system that uses a nonembryogenic maize BMS (Black Mexican Sweet) suspension cell culture (Spencer et al., 1990). Since its development in 1979, various studies have used this approach to investigate the subcellular (co-) localization of multiple candidate proteins (e.g., Uebler et al., 2015), among other applications. We detail the procedures to culture BMS cells on solid and in liquid medium, to prepare plasmids coated with gold particles, to bombard cells, and to image and analyze them using open-access software packages. These methods can be used to establish stable BMS cultures comparable to Arabidopsis PSB-D suspension cultures, which have been shown to be valuable, for example, for co-localization studies and biochemical assays to identify protein, RNA and DNA interaction partners of stable transformed candidate proteins (e.g., Antosz et al., 2017).

\section{Materials and Reagents}

1. Aluminum foil (Roth, catalog number: 2596.1)

2. Microscope Slides (VWR, catalog number: 631-1552)

3. Coverslips (VWR, catalog number: MENZBBAD024004SC13)

4. $25 \mathrm{ml}$ glass flask (VWR, catalog number: 214-0248)

5. $1.5 \mathrm{ml}$ microcentrifuge tubes (Sarstedt, catalog number: 72.706 .400 )

6. Petri dish $92 \times 16 \mathrm{~mm}$ with cams (Sarstedt, catalog number: 82.1473)

7. Petri dish $60 \times 15 \mathrm{~mm}$ with cams (Sarstedt, catalog number: 82.1194.500)

8. Parafilm (VWR, catalog number: 291-0057)

9. Corning cell strainer $40 \mu \mathrm{m}$ (Sigma-Aldrich, catalog number: CLS431750-50EA)

10. Sterile syringe filter, pore size $0.22 \mu \mathrm{m}$ (Berrytec, catalog number: 1302601)

11. $12 \mathrm{ml}$ Syringe (Norm-Ject, catalog number: 4100-000V0)

12. 1100 psi Rupture disks (Bio-Rad, catalog number 1652329)

13. $1.0 \mu \mathrm{m}$ Gold microcarriers (Bio-Rad, catalog number: 1652263)

14. Macrocarriers (Bio-Rad, catalog number: 1652335)

15. Macrocarrier holders (Bio-Rad, catalog number: 1652322)

16. Stopping screens (Bio-Rad, catalog number: 1652336)

17. BMS cell line (Arabidopsis Biological Resource Center ABRC, stock: CCL84842; see also Spencer et al., 1990)

18. proZmUbi:ZmEA1-GFP plasmid (from Uebler et al., 2015)

19. pro2x35S:ER-mCherry (ABRC, stock: CD3-959; see also Nelson et al., 2007)

20. Ethanol (Sigma-Aldrich, catalog number: 32205-1L-M)

21. Glycerol (Sigma-Aldrich, catalog number: G9012-2L)

22. Double distilled water $\left(\mathrm{ddH}_{2} \mathrm{O}\right)$, produced by MilliporeSigma Milli-Q Advantage A10 water purification system)

23. 2,4-Dichlorophenoxyacetic acid (Sigma-Aldrich, catalog number: D70724-5G)

24. Potassium hydroxide (KOH) (Merck, catalog number: 1.05033.1000) 
25. Gelrite (Duchefa Biochemie, catalog number: G1101)

26. PureLink HiPure Plasmid Midiprep Kit (Thermo Fisher Scientific, catalog number: K210004)

27. Calcium chloride $\left(\mathrm{CaCl}_{2}\right)$ (Roth, catalog number: 5239.1)

28. 0.1 M Spermidine solution (Sigma-Aldrich, catalog number: 05292-1ML-F)

29. MS salts (based on Murashige and Skoog, 1962) including vitamins (Duchefa Biochemie, catalog number: M0222)

30. Sucrose (Roth, catalog number: 4661.4)

31. Liquid MS medium (see Recipes)

32. MS plates (see Recipes)

\section{Equipment}

1. PDS-1000/He TM System (Bio-Rad, catalog number: 1652257)

2. Sterile laminar flow bench (KR Biowizard Golden Line Safety Cabinet, KR-130 GL or similar)

3. Vortex (Scientific Industries, model: Vortex-Genie 2)

4. Table centrifuge (Eppendorf, model 5424)

5. Pipette (Eppendorf, model: Research ${ }^{\circledR}$ plus, series in $2.5-1,000 \mu$ l volume)

6. $\mathrm{pH}$ meter (Mettler Toledo SevenEasy S20 pH Meter)

7. Steel sieve (size around $1.5-2 \mathrm{~mm}$, purchased in a supermarket)

8. Standard refrigerator $\left(4^{\circ} \mathrm{C}\right.$ and $\left.-20^{\circ} \mathrm{C}\right)$

9. Laboratory autoclave machine

10. Standard microwave oven

11. Spectrophotometer (Thermo Fisher Scientific, model: NanoDrop ${ }^{\mathrm{TM}}$ 1000, catalog number: ND1000)

12. Tissue culture incubator (for example from Binder allowing cultivation at $26{ }^{\circ} \mathrm{C}$ in the dark)

13. Compact incubation shaker (Minitron from Infors $\mathrm{HT}, 130 \mathrm{rpm}$ at $26^{\circ} \mathrm{C}$ in the dark)

14. Plant growth chamber (walk-in growth chamber or greenhouse; long-day growth conditions with $16 \mathrm{~h}$ of light at $28{ }^{\circ} \mathrm{C}$ and $8 \mathrm{~h}$ of dark at $22^{\circ} \mathrm{C}$ each at $65 \%$ relative humidity)

15. Confocal microscope (Zeiss LSM880, Leica SP8 or similar)

\section{Software}

1. ImageJ (National Institute of Health and the Laboratory for Optical Computational Instrumentation, http://imagej.nih.gov/ij, Schneider et al., 2012)

2. ZEN Lite software package (Zeiss, http://zeiss.com/microscopy/int/products/microscopesoftware/zen-lite.html) 


\section{Procedure}

A. Culture of BMS cells and preparation of suspension cells

1. Cultivated BMS cells were placed in $60 \mathrm{~mm}$ Petri dishes with a sterile spoon on solid MS medium as a cell layer in the dark at $26^{\circ} \mathrm{C}$ (Figure 1).

Note: Both liquid and solid MS medium can be stored at $4{ }^{\circ} \mathrm{C}$ for 4 weeks when they are sealed properly with caps and parafilm, respectively. Long term storage is not recommended.

2. Transfer cells to sterile plates containing fresh medium every two to three weeks to provide enough nutrients and keep cells at optimal growth conditions. It is essential to work under a sterile laminar flow bench.

Note: It is essential to cultivate and transfer cells in a sterile environment using laminar flow hoods, which are not used for work with bacteria and/or yeast. Alternatively, hood has to be sterilized very carefully to avoid contamination of slow growing plant cultures.

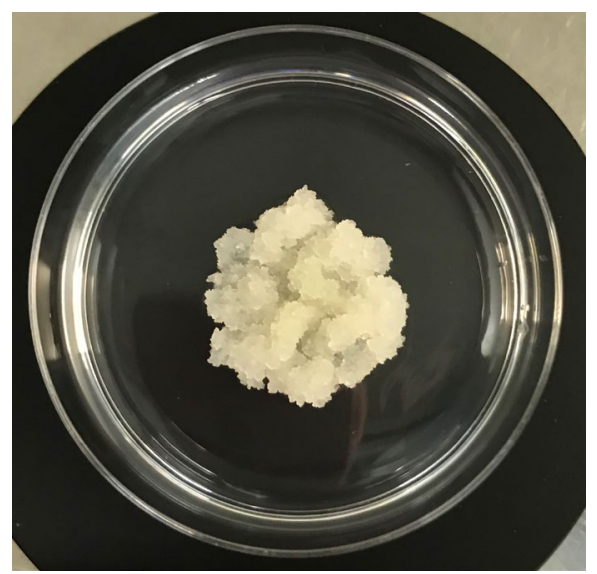

Figure 1. BMS cells grow on solid MS medium in the dark. $60 \mathrm{~mm}$ Petri dishes should be sealed using parafilm to keep cell cultures sterile.

3. To initiate a suspension cell culture, transfer $500 \mathrm{mg} \mathrm{BMS}$ cells from a solid MS plate into $4 \mathrm{ml}$ liquid MS medium within a sterile $25 \mathrm{ml}$ glass flask (Figures 2A-2B). Seal flask with aluminum foil and cultivate it with $130 \mathrm{rpm}$ shaking at $26{ }^{\circ} \mathrm{C}$ in the dark for 5-7 days. When cells form aggregates, filter them through a sterile steel sieve to maintain the uniform growth of suspension cells.

4. For particle bombardment, collect suspension cells using a sterile cell strainer with the pore size of $40 \mu \mathrm{m}$ (Figure $2 \mathrm{C}$ ). Allow the liquid to pass through and spread the cells on a new MS plate to form a thin layer in the center with a bending spoon (Figure 2D). Seal MS plates with parafilm and put it in the dark at $26{ }^{\circ} \mathrm{C}$ overnight. Now plates are ready for bombardment. 


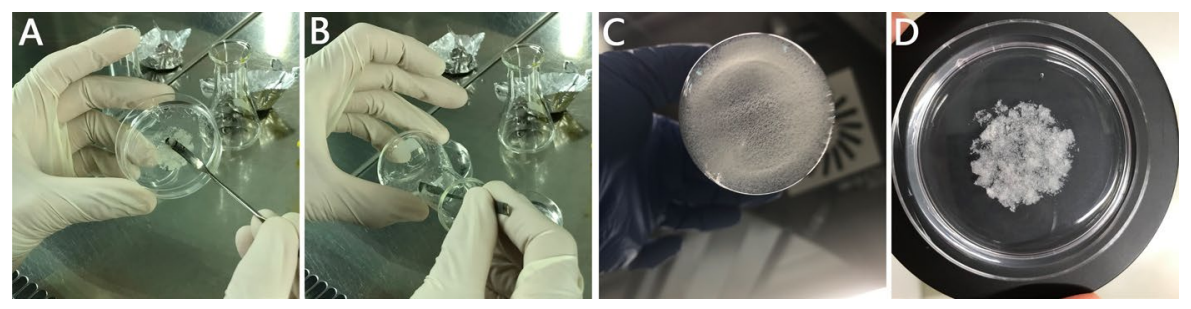

Figure 2. Cultivation of BMS suspension cells and preparation of BMS cell layer for bombardment. A. Collection of BMS cells with a bending spoon from solid MS plate. B. Transfer of BMS cells into liquid MS medium using a sterile bending spoon. C. BMS suspension cells grown in a $25 \mathrm{ml}$ glass flask photographed from the bottom. D. MS plate with a thin layer of BMS cells in the center, ready for transformation.

B. Gold particle preparation

1. Put $60 \mathrm{mg} 1 \mu \mathrm{m}$ gold particles into a $1.5 \mathrm{ml}$ microcentrifuge tube, add $1 \mathrm{ml} 70 \%$ ethanol, vortex at full speed for $1 \mathrm{~min}$ and incubate at room temperature for $15 \mathrm{~min}$.

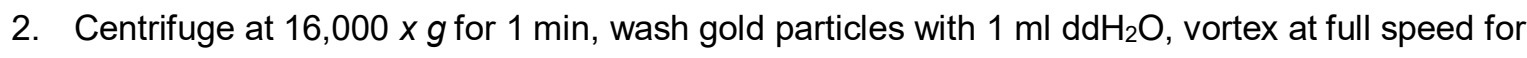
$1 \mathrm{~min}$ and centrifuge for $1 \mathrm{~min}$ at $16,000 \times \mathrm{g}$.

3. Remove the supernatant and repeat Step B2 for another two times.

4. Add $1 \mathrm{ml} 50 \%$ glycerol ( $\mathrm{w} / \mathrm{v}$ in water) into the tube and vortex for $1 \mathrm{~min}$ to resuspend gold particles. Aliquot $25 \mu \mathrm{l}$ re-suspended gold particles into new tubes and store at $-20^{\circ} \mathrm{C}$.

5. Prepare expression plasmids using plasmid midi preparation kits according to instructions of the suppliers.

6. Place macrocarrier into macrocarrier holder (Figure $3 \mathrm{~A}$ ) and seat it firmly to the bottom with the red caplugs RC-14 (Figure 3B), which is included in the Optimization kit of the PDS-1000/He system. Prepare three macrocarrier sets for each transformation and place all three sets into a $92 \mathrm{~mm}$ Petri dish (Figure 3C).
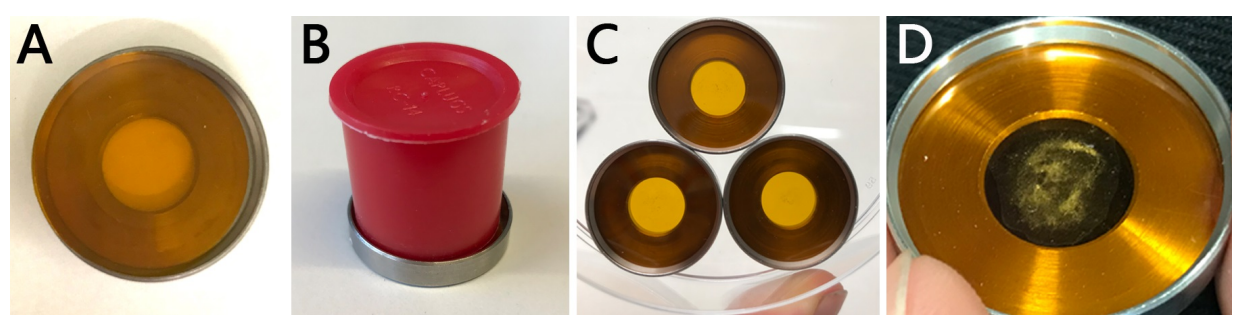

Figure 3. Macrocarrier set preparation. A. A piece of macrocarrier on top of a steel holder.

B. Red caplugs on top of the steel holder with macrocarrier. C. Three macrocarriers for each transformation in a Petri dish. D. Macrocarrier after loading a DNA-gold mixture in the middle. Note: After drying, a thin white layer is visible in the center over the hole of a macrocarrier holder (Figure 3D). 
7. Add all components into a $1.5 \mathrm{ml}$ centrifuge tube with the following order:

$\begin{array}{ll}\mathrm{ddH}_{2} \mathrm{O} & \text { up to } 75 \mu \mathrm{l} \\ \text { plasmid } & 10 \mu \mathrm{g} \\ \text { gold particles } & 12.5 \mu \mathrm{l}\end{array}$

If co-transformation of 2 plasmids is performed, use $5 \mu \mathrm{g}$ of each plasmid and perform the transformation procedure exactly as done by single plasmid transformation.

8. Vortex the mixture for $5 \mathrm{~s}$ at full speed (all vortex steps below should be performed at full speed), add $50 \mu \mathrm{l}$ filter-sterilized $2.5 \mathrm{M} \mathrm{CaCl}_{2}$ into the tube and vortex for $5 \mathrm{~s}$, then add $20 \mu \mathrm{l} 0.1 \mathrm{M}$ Spermidine and vortex for $90 \mathrm{~s}$.

9. Spin down for $10 \mathrm{~s}$ at $10,000 \times g$ and remove the supernatant.

10. Wash DNA-gold mixture with $200 \mu \mathrm{l}$ pure ethanol, vortex for $5 \mathrm{~s}$ and spin down again for $10 \mathrm{~s}$ at $10,000 \times g$.

11. Repeat Step B10 once and resuspend the mixture with $30 \mu \mathrm{l}$ pure ethanol.

12. Thoroughly resuspend the mixture by vortexing and pipetting to avoid big aggregates, load 10 $\mu$ I DNA-gold mixture on each microcarrier. Note that particles should be placed only in the center over the holes of macrocarrier holders. Air dry the macrocarriers on the bench for several minutes. Finally, a thin white layer can be observed (Figure 3D).

C. Bombardment of BMS cells and cultivation

1. Switch on the helium tank and the vacuum pump; they provide pressure for the DNA delivery system and generate vacuum in the bombardment chamber, respectively. Make sure that the helium tank has at least a 1300 psi inside pressure.

2. Assemble all components as follows:

a. Place a piece of $1100 \mathrm{psi}$ rapture disk into the rupture disk retaining cap and make sure that it perfectly covers the bottom (Figure 4A).

b. Screw the rupture disk retaining cap to the gas acceleration tube within the bombardment chamber and fasten it by turning the torque wrench to the right side.

c. To assemble the microcarrier launch unit, place the stopping screen first in the middle of the fixed nest (Figure 4B), then place the macrocarrier set upside down on top of the stopping screen (Figure 4C).

d. Apply the macrocarrier cover lid on top and fasten it properly (Figure 4D), and finally insert it into the first level of the bombardment chamber.

e. Open a $60 \mathrm{~mm}$ Petri dish with BMS cells, place it in the middle of the target plate shelf and insert it into the third level of the bombardment chamber (Figure 4E).

f. Close and latch the chamber door. 


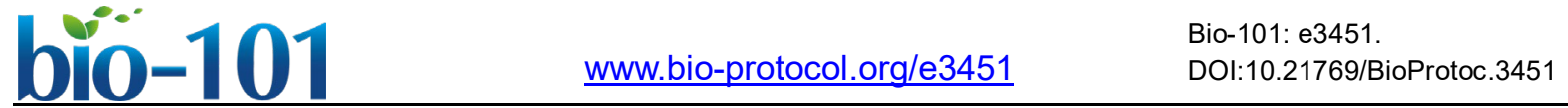

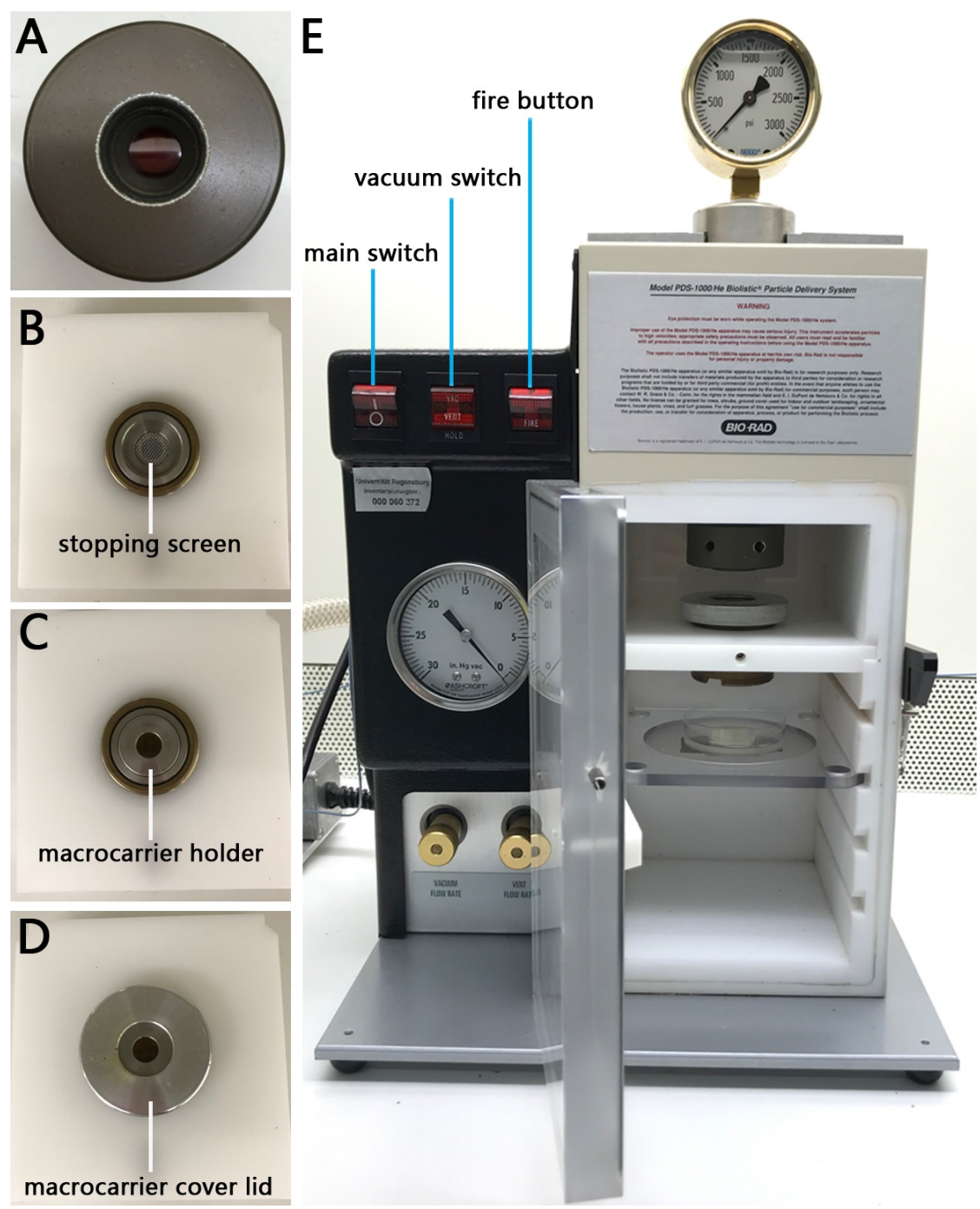

Figure 4. PDS-1000/He bombardment chamber assembly. A. Rupture disk retaining cap with rupture disk inside. B. Microcarrier launch unit with stopping screen. C. Microcarrier launch unit with macrocarrier holder. D. Fully assembled microcarrier launch unit covered with lid. E. Position of the different units described above inside of the bombardment chamber.

3. Turn on the main switch of the PDS-1000/He TM System with the red button on the left side.

a. Evacuate the bombardment chamber with setting the vacuum switch (middle red button) to the VAC position.

b. When the vacuum level reaches about 23 in $\mathrm{Hg}$ (based on the vacuum gauge), quickly press the vacuum control switch through the middle VENT position to the bottom HOLD position.

c. Press and hold the FIRE button on the right side to allow the helium pressure to build inside of the gas acceleration tube. When the pressure reaches to around 1,100 psi (which can be observed by the helium pressure gauge at the top of the acceleration tube), there will be a small pop sound because of the burst of the rupture disk.

d. Release the FIRE button and change the vacuum switch to VENT in the middle position to release the vacuum completely. 
e. Open the chamber door and take the BMS cells out from the target plate shelf, close the Petri dish cap immediately and unscrew the rupture disk retaining cap.

f. Remove the microcarrier launch unit, discard the broken rupture disk and the used macrocarrier as well as stopping screen.

g. Generate a new assemble as described above (from Steps 3a-3f) and start another bombardment.

Note: There is no need to perform bombardment under a sterile laminar flow hood, although cells will be cultivated on solid MS medium overnight and then being transferred into liquid medium after transformation. Within this short time period between transformation and observation, there is no visible contamination from bacteria or fungi that disturb and affect analyses. However, for the generation of stable transformed suspension cultures-which is not further detailed here-we recommend performing transformation by using a sterile laminar flow hood.

4. After bombardment, place the Petri dish containing BMS cells into the dark growth chamber and incubate overnight at $26^{\circ} \mathrm{C}$.

5. Use a sterile bending spoon, transfer the BMS cell layer into a new $25 \mathrm{ml}$ flask with $4 \mathrm{ml}$ liquid MS medium inside (Figures 5A-5B). Shake the suspension cells at $26^{\circ} \mathrm{C}$ in the dark at $130 \mathrm{rpm}$ for at least $4 \mathrm{~h}$.

6. Load $40 \mu \mathrm{l}$ cell culture on a glass slide and cover it with a coverslip. Image cells using a confocal or fluorescence light microscope.
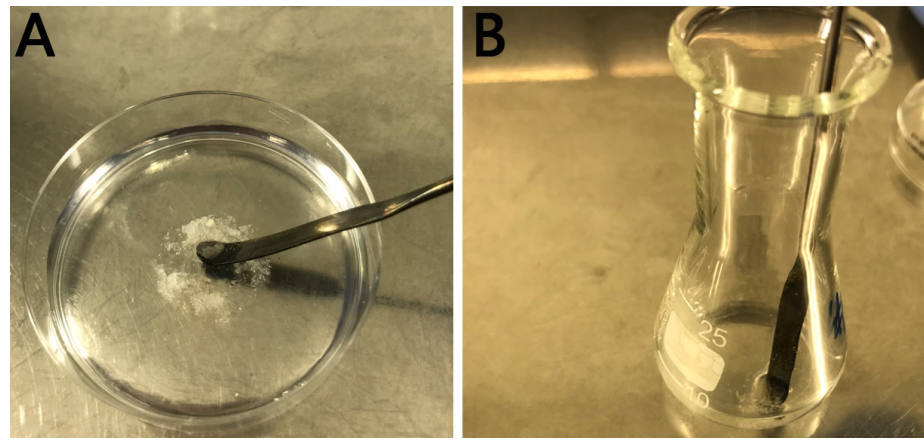

Figure 5. Re-suspend BMS cells after transformation. A. Collect BMS cells with a bending spoon. B. BMS cells in liquid MS medium after resuspension.

\section{Data analysis}

1. Screen sample glass slides containing BMS cells ideally by using a confocal laser microscope (CLSM) using a 10x objective with corresponding filter sets. Positively transformed cells with bright fluorescent can be found (Figures $6 \mathrm{~A}-6 \mathrm{C}$ ). Change to $40 \mathrm{x}$ or $63 \mathrm{x}$ oil objective for taking pictures of single cell (Figures 6D-6F). 

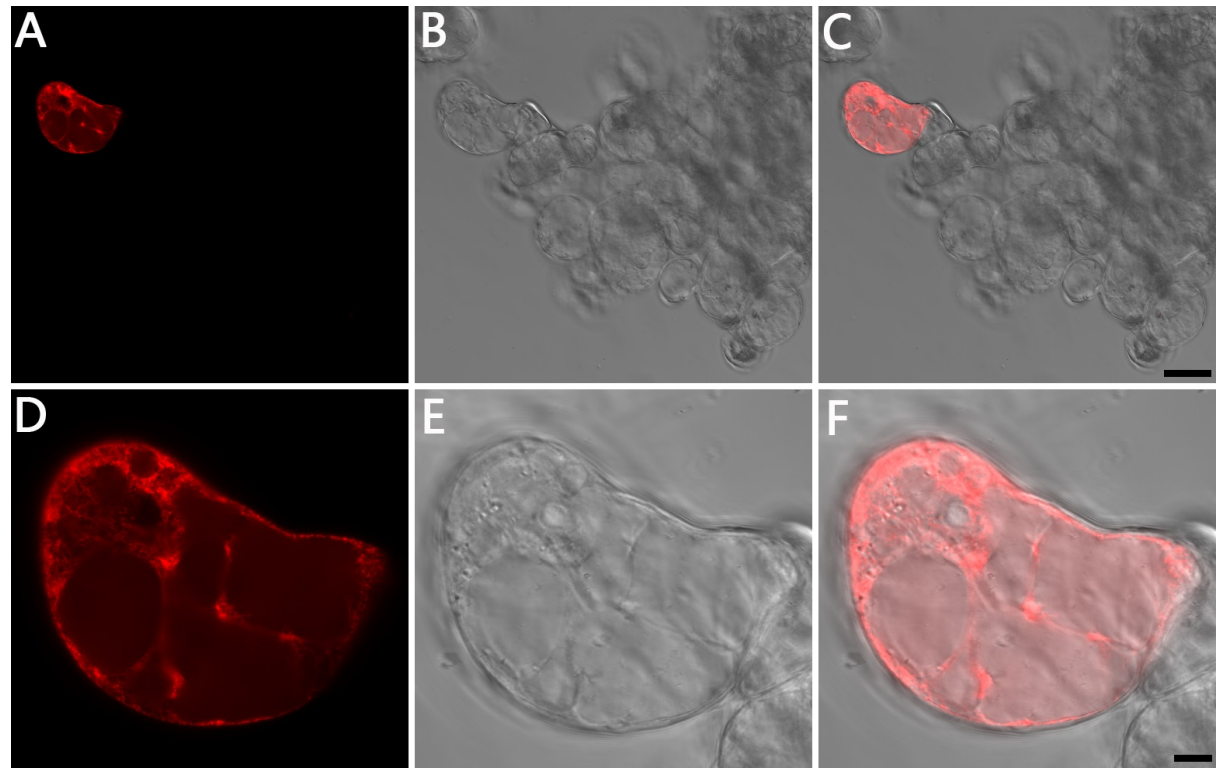

Figure 6. BMS cells transformed with an endoplasmic reticulum marker ER-mCherry using the $35 \mathrm{~S}$ promoter. A-C. Transformed BMS cells using a 10x objective. Only positively transformed cells show strong fluorescent. Scale bar $=50 \mu \mathrm{m}$. D-F. Enlargement of A-C using a $63 x$ oil objective. Scale bar $=10 \mu \mathrm{m}$. Vector from Uebler et al., 2015.

2. Co-localization of different proteins can be analyzed by using the plot profile function of ImageJ.

a. Obtain a merged image from the CLSM software (e.g., Zen Lite) with different channels.

b. Open ImageJ software, drag the merged image and drop it in the ImageJ bar.

c. Click "Image-color-split channels" to create images with separate channels. Then click "Image-color-merge channels", choose channels with proper colors (for example red/green or magenta/green) and create composite. Click "OK" to generate a new merged image.

d. Use the selection tool "Straight line" to pick area of interest, then click "Analyze-plot profile" to generate plots of composites. By clicking "Live" and dragging the horizontal scrolling slider of the composite image, a plot image of different channels can be observed.

e. Click "List" in the bottom left, save the gray value under "File-save as" as Excel file. Select the data in Excel file, click "Insert-line-line" and the plot profile will be created.

f. Overlapping of different channels in line chart indicates co-localization (Figures 7A-7E), while non-overlapping of different channels indicates lack of co-localization (Figures 7F-7J). 

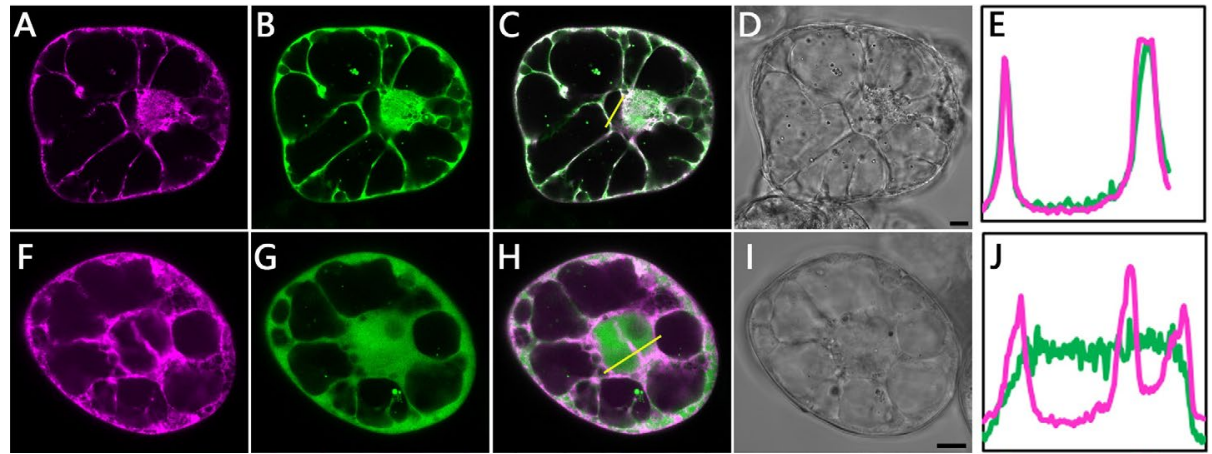

Figure 7. Co-localization analysis of BMS cells after co-transformation. A-D. BMS cell transformed with endoplasmic reticulum marker ER-mCherry (magenta) and ZmEA1-GFP (green). E. Plot profile of the single channels indicated by the thin white line in C. Co-localization can be observed between ER marker and ZmEA1. F-I. BMS cell transformed with ER-mCherry (magenta) and cytosolic GFP (green). J. Plot profile of the thin white line in $\mathrm{H}$. The plot indicates that there is no co-localization between the ER marker and free GFP. All vectors are from Uebler et al., 2015. Scale bars $=10 \mu \mathrm{m}$.

\section{$\underline{\text { Recipes }}$}

1. Liquid MS medium

$30 \mathrm{~g} / \mathrm{L}$ sucrose

$4.4 \mathrm{~g} / \mathrm{L}$ MS-salts

$2 \mathrm{mg} / \mathrm{L}$ 2,4-Dichlorophenoxyacetic

Adjust $\mathrm{pH}$ to 5.8 with $1 \mathrm{M} \mathrm{KOH}$, filter sterilize

Note: MS medium can be stored at $4{ }^{\circ} \mathrm{C}$ for 4 weeks.

2. MS plate

Liquid MS medium with $0.3 \%$ Gelrite

Prepare $2 x$ filter-sterilized liquid MS medium

Autoclave $0.6 \%$ Gelrite and microwave it to liquid before using

Mix these two components 1:1 to make plates by using a sterile laminar flow hood

Note: Parafilm sealed MS plates can be stored at $4^{\circ} \mathrm{C}$ for up to 4 weeks.

\section{Acknowledgments}

Annemarie Taffner is acknowledged for regular subculture of BMS cells. Work on maize in the Dresselhaus lab is funded by the German Research Council DFG via Collaborative Research Center SFB924. 


\section{Competing interests}

The authors declare no conflict of interest.

\section{References}

1. Amien, S., Kliwer, I., Marton, M. L., Debener, T., Geiger, D., Becker, D. and Dresselhaus, T. (2010). Defensin-like ZmES4 mediates pollen tube burst in maize via opening of the potassium channel KZM1. PLoS Biol 8(6): e1000388.

2. Anand, A., Wu, E., Li, Z., TeRonde, S., Arling, M., Lenderts, B., Mutti, J. S., Gordon-Kamm, W., Jones, T. J. and Chilcoat, N. D. (2019). High efficiency Agrobacterium-mediated site-specific gene integration in maize utilizing the FLP-FRT recombination system. Plant Biotechnol J 17(8): 1636-1645.

3. Antosz, W., Pfab, A., Ehrnsberger, H. F., Holzinger, P., Köllen, K., Mortensen, S. A., Bruckmann, A., Schubert, T., Längst, G., Griesenbeck, J., Schubert, V., Grasser, M. and Grasser, K. D. (2017). The composition of the Arabidopsis RNA polymerase II transcript elongation complex reveals the interplay between elongation and mRNA processing factors. Plant Cell 29(4): 854870.

4. Dresselhaus, T., Lausser, A. and Márton, M. L. (2011). Using maize as a model to study pollen tube growth and guidance, cross-incompatibility and sperm delivery in grasses. Ann Bot 108(4): 727-737.

5. Jiao, Y., Peluso, P., Shi, J., Liang, T., Stitzer, M. C., Wang, B., Campbell, M. S., Stein, J. C., Wei, X., Chin, C. S., Guill, K., Regulski, M., Kumari, S., Olson, A., Gent, J., Schneider, K. L., Wolfgruber, T. K., May, M. R., Springer, N. M., Antoniou, E., McCombie, W. R., Presting, G. G., McMullen, M., Ross-Ibarra, J., Dawe, R. K., Hastie, A., Rank, D. R. and Ware, D. (2017). Improved maize reference genome with single-molecule technologies. Nature 546(7659): 524527.

6. Juranić, M., Srilunchang, K. O., Krohn, N. G., Leljak-Levanić, D., Sprunck, S. and Dresselhaus, T. (2012). Germline-specific MATH-BTB substrate adaptor MAB1 regulates spindle length and nuclei identity in maize. Plant Cell 24(12): 4974-4991.

7. Murashige, T. and Skoog, F. (1962). A revised medium for rapid growth and bioassays with tobacco tissue cultures. Physiol Plant 15(3): 473-497.

8. Nelson, B. K., Cai, X., \& Nebenführ, A. (2007). A multicolored set of in vivo organelle markers for co-localization studies in Arabidopsis and other plants. Plant J 51(6): 1126-1136.

9. Schnable, P. S., Ware, D., Fulton, R. S., Stein, J. C., Wei, F., Pasternak, S., Liang, C., Zhang, J., Fulton, L., Graves, T. A., Minx, P., Reily, A. D., Courtney, L., Kruchowski, S. S., Tomlinson, C., Strong, C., Delehaunty, K., Fronick, C., Courtney, B., Rock, S. M., Belter, E., Du, F., Kim, K., Abbott, R. M., Cotton, M., Levy, A., Marchetto, P., Ochoa, K., Jackson, S. M., Gillam, B., Chen, W., Yan, L., Higginbotham, J., Cardenas, M., Waligorski, J., Applebaum, E., Phelps, L., 
Falcone, J., Kanchi, K., Thane, T., Scimone, A., Thane, N., Henke, J., Wang, T., Ruppert, J., Shah, N., Rotter, K., Hodges, J., Ingenthron, E., Cordes, M., Kohlberg, S., Sgro, J., Delgado, B., Mead, K., Chinwalla, A., Leonard, S., Crouse, K., Collura, K., Kudrna, D., Currie, J., He, R., Angelova, A., Rajasekar, S., Mueller, T., Lomeli, R., Scara, G., Ko, A., Delaney, K., Wissotski, M., Lopez, G., Campos, D., Braidotti, M., Ashley, E., Golser, W., Kim, H., Lee, S., Lin, J., Dujmic, Z., Kim, W., Talag, J., Zuccolo, A., Fan, C., Sebastian, A., Kramer, M., Spiegel, L., Nascimento, L., Zutavern, T., Miller, B., Ambroise, C., Muller, S., Spooner, W., Narechania, A., Ren, L., Wei, S., Kumari, S., Faga, B., Levy, M. J., McMahan, L., Van Buren, P., Vaughn, M. W., Ying, K., Yeh, C. T., Emrich, S. J., Jia, Y., Kalyanaraman, A., Hsia, A. P., Barbazuk, W. B., Baucom, R. S., Brutnell, T. P., Carpita, N. C., Chaparro, C., Chia, J. M., Deragon, J. M., Estill, J. C., Fu, Y., Jeddeloh, J. A., Han, Y., Lee, H., Li, P., Lisch, D. R., Liu, S., Liu, Z., Nagel, D. H., McCann, M. C., SanMiguel, P., Myers, A. M., Nettleton, D., Nguyen, J., Penning, B. W., Ponnala, L., Schneider, K. L., Schwartz, D. C., Sharma, A., Soderlund, C., Springer, N. M., Sun, Q., Wang, H., Waterman, M., Westerman, R., Wolfgruber, T. K., Yang, L., Yu, Y., Zhang, L., Zhou, S., Zhu, Q., Bennetzen, J. L., Dawe, R. K., Jiang, J., Jiang, N., Presting, G. G., Wessler, S. R., Aluru, S., Martienssen, R. A., Clifton, S. W., McCombie, W. R., Wing, R. A. and Wilson, R. K. (2009). The B73 maize genome: complexity, diversity, and dynamics. Science 326(5956): 1112-1115.

10. Schneider, C. A., Rasband, W. S. and Eliceiri, K. W. (2012). NIH Image to ImageJ: 25 years of image analysis. Nat Methods 9(7): 671-675.

11. Shiferaw, B., Prasanna, B. M., Hellin, J. and Bänzinger, M. (2011). Crops that feed the world. 6. Past successes and future challenges to the role played by maize in global food security. Food Sec 3: 307.

12. Spencer, T. M., Gordon-Kamm, W. J., Daines, R. J., Start, W. G. and Lemaux, P. G. (1990). Bialaphos selection of stable transformants from maize cell culture. Theor Appl Genet 79(5): 625-631.

13. Srilunchang, K. O., Krohn, N. G. and Dresselhaus, T. (2010). DiSUMO-like DSUL is required for nuclei positioning, cell specification and viability during female gametophyte maturation in maize. Development 137(2): 333-345.

14. Sun, S., Zhou, Y., Chen, J., Shi, J., Zhao, H., Zhao, H., Song, W., Zhang, M., Cui, Y., Dong, X., Liu, H., Ma, X., Jiao, Y., Wang, B., Wei, X., Stein, J. C., Glaubitz, J. C., Lu, F., Yu, G., Liang, C., Fengler, K., Li, B., Rafalski, A., Schnable, P. S., Ware, D. H., Buckler, E. S. and Lai, J. (2018). Extensive intraspecific gene order and gene structural variations between Mo17 and other maize genomes. Nat Genet 50(9): 1289-1295.

15. Uebler, S., Marton, M. L. and Dresselhaus, T. (2015). Classification of EA1-box proteins and new insights into their role during reproduction in grasses. Plant Reprod 28(3-4): 183-197. 